\title{
Novel Protease from Aspergillus tamarii URM4634: Production and Characterization Using Inexpensive Agroindustrial Substrates by Solid-State Fermentation
}

\author{
Osmar Soares da Silva1, Rodrigo Lira de Oliveira², Cristina Maria Souza-Motta ${ }^{3}$, \\ Ana Lúcia Figueiredo Porto ${ }^{4}$, Tatiana Souza Porto ${ }^{1,2,4}$
}

${ }^{1}$ Northeast Biotechnology Network/RENORBIO, Federal Rural University of Pernambuco (UFRPE), Recife, Brazil

${ }^{2}$ Academic Unity of Garanhuns/UAG, Federal Rural University of Pernambuco (UFRPE), Garanhuns, Brazil

${ }^{3}$ Department Mycology, Federal University of Pernambuco (UFPE), Recife, Brazil

${ }^{4}$ Department of Morphology Physiology Animal/DMFA, Federal Rural University of Pernambuco (UFRPE), Recife, Brazil

Email: portots@yahoo.com.br

How to cite this paper: da Silva, O.S., de Oliveira, R.L., Souza-Motta, C.M., Porto, A.L.F. and Porto, T.S. (2016) Novel Protease from Aspergillus tamari URM4634: Production and Characterization Using Inexpensive Agroindustrial Substrates by Solid-State Fermentation. Advances in Enzyme Research, 4, 125-143.

http://dx.doi.org/10.4236/aer.2016.44012

Received: September 6, 2016

Accepted: November 29, 2016

Published: December 2, 2016

Copyright $\odot 2016$ by authors and Scientific Research Publishing Inc. This work is licensed under the Creative Commons Attribution International License (CC BY 4.0).

http://creativecommons.org/licenses/by/4.0/ (c) (i) Open Access

\begin{abstract}
This study reports the protease production from Aspergillus tamarii using agroindustrial residues as substrate for solid-state fermentation (SSF) and biochemical characterization. The highest protease production was obtained using wheat bran as substrate at $72 \mathrm{~h}$ fermentation with maximum proteolytic activity of $401.42 \mathrm{U} / \mathrm{mL}$, collagenase of $243.0 \mathrm{U} / \mathrm{mL}$ and keratinase of $19.1 \mathrm{U} / \mathrm{mL}$. The protease exhibited $\mathrm{K}_{\mathrm{M}}=$ $18.7 \mathrm{mg} / \mathrm{mL}$ and $\mathrm{Vmax}=28.5 \mathrm{mg} / \mathrm{mL} / \mathrm{min}$. The optimal $\mathrm{pH}$ was 8.0 and stable in a wide $\mathrm{pH}$ range $(5.0-11.0)$ during $24 \mathrm{~h}$. The optimum temperature was $40^{\circ} \mathrm{C}$. The proteolytic activity was inhibited by $\mathrm{Cu}^{2+}(33.98 \%)$ and $\mathrm{Hg}^{2+}(22.69 \%)$. The enzyme was also inhibited by PMSF (65.11\%), indicating that is a Serine Protease. These properties suggest that alkaline protease from $A$. tamarii URM4634 is suitable for application in food industries and leather processing. Additionally, the present findings opened new vistas in the utilization of wheat bran and other effective agroindustrial wastes as substrates for SSF.
\end{abstract}

\section{Keywords}

Protease, Aspergillus tamarii, Biochemical Characterization, Solid-State Fermentation, Agroindustrial Waste

\section{Introduction}

Proteases catalyze the cleavage of peptide bonds in proteins, are the class of enzymes 
having applications in both physiological and commercial fields. Among all the different commercial enzymes, microbial protease in particular, consisting of more than $25 \%$ of biomolecules produced for industrial application and 65\% of all the industrial enzymes sales in the world due to their applications in several industrial sectors like in the detergent, food, pharmaceuticals, chemicals, leather, paper and pulp and silk industries [1] [2] [3] [4].

Proteases can be obtained from several sources, including plants, animals, and microorganisms. Even though a wide variety of microbial proteases are available, the use of these enzymes on industrial scale is still limited by their high production costs and the fact that their activity is often limited to a restricted range of biochemical characteristics [5].

The Solid State Fermentation (SSF) is especially suitable for the fungi growth because their moisture requirements are lower compared to the bacteria. In this technique, the enzymes produced are more concentrated than those in submerged fermentation. SSF is an inexpensive technique and can be widely applied to agricultural products or by-products as substrates. Furthermore, the substrate must be easy to handle, inexpensive and easy to purchase. The overall cost of enzyme production is very high (due to high cost of substrates and mediums used). Therefore, development of novel processes to increase the yield of proteases with respect to their industrial requirements coupled with lowering down the production cost is highly appreciable from the commercial point of view [6].

SSF is also a cost-effective process as it uses agroindustrial wastes, like seeds, peels, husks, bark, and bran to produce valuable bioactive molecules. Another important advantage of SSF is the higher growth rate exhibited by fungi on solid substrate as compared to submerged fermentation; the morphology of filamentous fungi allows them to colonize the substrate surface and matrix in search of nutrients, consequently secreting higher levels of metabolites and enzymes [5].

Filamentous fungi, such as Aspergillus spp., are explored for the production of industrial enzymes due to their ability to grow on solid or liquid substrates and having a large production of extracellular enzymes. Some strains from Aspergillus genus are considered non-toxic, recognized as a safe microorganism by the Food and Drug Administration (FDA), denominated Generally Recognized as Safe (GRAS), and used for human and animal nutrition [5] [6] [7].

In the Brazilian scenario, which is heavily focused on agriculture economy; especially soy, wheat, corn and sugarcane, the technological potential for efficient reuse of agro industrial waste can contribute to the development of high added value products such as enzymes, organic acids, flavors and fragrances, pigments, polysaccharides and hormones, adding value to this residue produced in large quantities [5].

In this study, we evaluated the inexpensive production of proteases from several GRAS fungal strains, using agroindustrial waste: wheat grains, Canadian lentils, amaranth flakes, soybean grains, nuggets sunflower, oat bran and wheat bran. The different residues used as substrate can modify fungi metabolic expression and produce enzymes with distinct characteristics, which can be applied in the biotechnological industry in 
many ways. The combination of the microbial cell and different substrates comprises metabolic and biotransformation process that can generate several cellular products. Additionally, the microorganism and substrate selection plus the biochemical characteristic of the enzyme produced are important factors to evaluate its biotechnological potential and target the possible applications for industrial processes [5] [6] [7] [8]. The aim of this study was to produce in different agroindustrial substrates and characterize extracellular protease from Aspergillus tamarii URM4634 by Solid-state Fermentation.

\section{Material and Methods}

\subsection{Microorganism}

The thirty-four Aspergillus strains used for screening were provided by the "MicotecaURM" of Mycology Department, Centre of Biological Sciences of Federal University of Pernambuco (UFPE), Recife-PE, Brazil. The strain was preserved in mineral oil [9], maintaining at $28^{\circ} \mathrm{C}$ in a Czapek Dox Agar medium. The microorganisms were grown in reactivation broth: $1 \%$ peptone; $0.3 \%$ beef extract; $2 \%$ glucose and $1000 \mathrm{~mL}$ of distilled water ( $\mathrm{pH}$ 7.0). After 5 days of growth, microorganisms were inoculated in Czapek Dox agar for 7 days at $30^{\circ} \mathrm{C}$.

\subsection{Screening and Culture Condition for Microorganisms of Aspergillus Genus}

Inoculum spores were produced in Czapek Dox Agar tubes inclined containing a culture seven-days-old culture grown at $30^{\circ} \mathrm{C}$ and suspended in a $3.0 \mathrm{~mL}$ of a solution consisting of $0.9 \% \mathrm{NaCl}$ and $0.01 \%$ Tween 80 , which was previously sterilized at $121^{\circ} \mathrm{C}$ for 20 min. Aspergillus strains were inoculated $\left(10^{4}\right.$ spores $\left./ \mathrm{mL}\right)$ in soybean flour medium MS-2 [10]. The submerged fermentation ( $\mathrm{SmF}$ ) was performed in $250 \mathrm{~mL}$-Erlenmeyer flasks contained $50 \mathrm{~mL}$ of production medium at $\mathrm{pH} 7.2$, for $72 \mathrm{~h}, 120 \mathrm{rpm}$ at $30^{\circ} \mathrm{C}$.

After fermentation, the culture medium was centrifuged at $3000 \mathrm{~g}$ for $15 \mathrm{~min}$ at $4^{\circ} \mathrm{C}$ to obtain the supernatant (enzyme crude extract). The screening of the microorganisms was performed in two steps. The first one was performed in submerged fermentation $(\mathrm{SmF})$ and the second step was performed in solid-state fermentation (SSF), using different substrates.

\subsection{Protease Production by Solid-State Fermentation (SSF)}

The substrates used for screening by SSF were: Wheat grains, Wheat bran, Oat bran, Soybeans, Canadian Lentils, Flakes amaranth, Quinoa flakes and Nuggets Sunflower, obtained in the local market in the city of Garanhuns, Pernambuco, Brazil.

SSF was performed in $125 \mathrm{~mL}$-Erlenmeyer flasks containing $5 \mathrm{~g}$ of each agroindustrial substrate, nutrition solution and $10^{7}$ spores $/ \mathrm{mL}$, corresponding to $40 \%$ moisture content. SSF was run for $72 \mathrm{~h}$ at $30^{\circ} \mathrm{C}$ and the protease extract was obtained by addition of $7.5 \mathrm{~mL}$ of $0.1 \mathrm{M}$ sodium phosphate ( $\mathrm{pH}$ 7.0) per gram of fermented material and homogenized in shaker for $2 \mathrm{~h}$. Solids were removed by centrifugation at $3000 \mathrm{~g}$ for 15 $\min$ at $4^{\circ} \mathrm{C}$, and the supernatant was used as enzyme crude extract. 
The experiments for protease production were performed according to a $2^{3}$-full factorial design. The analyzed variables were: Substrate (3, 5 and $7 \mathrm{~g})$; Moisture (30\%, 40\% and $50 \%)$; Temperature $\left(25^{\circ} \mathrm{C}, 30^{\circ} \mathrm{C}\right.$ and $\left.35^{\circ} \mathrm{C}\right)$. The central point runs were performed in quadruplicate to allow for pure error estimation. All graphic statistical analyses were made using the software Statistica 8.0 [11].

\subsection{Determination of Proteases Activities}

The protease activity was measured using azocasein as substrate described by Ginther [12]. One activity unit (U) was expressed as the amount of enzyme able to lead to a 0.1 increase in absorbance at $420 \mathrm{~nm}$ within $1 \mathrm{~h}$.

The collagenase activity was performed using the Azocoll method described by Chavira et al. [13]. One activity unit (U) was expressed as the amount of enzyme able to lead to a 0.1 increase in absorbance ate $520 \mathrm{~nm}$ with $3 \mathrm{~h}$.

The Keratinase activity was assayed by Anbu et al. [14]. One unit of the keratinase activity was expressed as the amount of enzyme able to lead to a 0.1 increase in absorbance at $280 \mathrm{~nm}$ with $1 \mathrm{~h}$.

\subsection{Determination of Biomass Estimation by Glucosamine Level}

Fungal biomass estimation was carried out according to Castro et al. [8] by measuring the levels of glucosamine, the basic unit of chitin. Glucosamine was detected by spectrometry after depolymerization of the chitin and the $\mathrm{N}$-acetyl glucosamine content, which is proportional to the fungal biomass. The measurements were taken after the acid hydrolysis of the biomass at $100^{\circ} \mathrm{C}$ where glucosamine hydrochloride undergoes successive reductions leading to chromogen III formation, which then reacts with a dimethyl-p-aminobenzaldehyde solution (Erlich solution) and produces red coloration that can be detected at $530 \mathrm{~nm}$.

\subsection{Mycotoxin Detection}

\subsubsection{Coconut Milk Based Medium Test}

Coconut milk agar medium (CMA) were based on Lin and Dianese [15] with some modifications. The $\mathrm{pH}$ was adjusted to 6.9 with $2 \mathrm{M} \mathrm{NaOH}$. Bacto agar $(15 \mathrm{~g} / \mathrm{L})$ was added, the mixture heated to boiling and autoclaved at $121^{\circ} \mathrm{C}$ for $20 \mathrm{~min}$. The plate center was inoculated with a concentration $10^{4}$ spores $/ \mathrm{mL}$ and $5 \mu \mathrm{L}$ of spore suspension was incubated in the dark at $28^{\circ} \mathrm{C}$. The presence or absence of a fluorescence ring in the agar surrounding the colonies under UV-A $365 \mathrm{~nm}$ light after seven days of incubation was noted and the results were scored as positive or negative for mycotoxin production.

\subsubsection{Ammonia Vapour Test}

Briefly, $25 \mathrm{~mL}$ of YES agar was inoculated as single colonies in the center of Petri-dishes and incubated in the dark at $28^{\circ} \mathrm{C}$ [16] [17]. After three days, a set of Petri-dishes were inverted over $2.0 \mathrm{~mL}$ of ammonium hydroxide. This was repeated with another set after seven days. After ten minutes, the undersides of aflatoxin producing isolates turned 
from pink to red color, but no color change occurred in the non-toxic isolates.

\subsection{Determination of the Kinetic Parameters ( $\left.\mathrm{K}_{\mathrm{M}}, \mathrm{Vmax}\right)$}

The kinetic parameters of the enzyme were determined using different concentrations of azocasein $\left(2 \leq \mathrm{S}_{0} \leq 100 \mathrm{mg} / \mathrm{mL}\right)$ for protease activity (section 2.4). All tests were carried out in triplicate and results were expressed as average values. Statistical analysis was performed using standard deviations of experimental data from the average values.

\subsection{Biochemical Characterization}

For biochemical characterization, the optimal activity and stability of enzymes at different $\mathrm{pH}$ and temperature, effects of metal ions and inhibitors were tested using enzymes produced in the best fermentation condition from Aspergillus tamarii URM4634 by SSF, according to 2.4 section.

\subsubsection{Effect of pH on Proteolytic Activity and Stability}

The optimum $\mathrm{pH}$ for protease activity was determined using different buffers $0.2 \mathrm{M}$ : citrate-phosphate $(\mathrm{pH} 5.0$ - 7.0), Tris- $\mathrm{HCl}(\mathrm{pH} 7.0$ - 8.5) and glycine- $\mathrm{NaOH}(\mathrm{pH} 8.5-$ 11.0). The effect of $\mathrm{pH}$ on stability of the enzyme was verified by a previous incubation of the enzyme crude extract with above buffers at $5^{\circ} \mathrm{C}$. Aliquots were analyzed to determine residual protease activity at time intervals $0 \mathrm{~h}, 4 \mathrm{~h}, 8 \mathrm{~h}$ and $24 \mathrm{~h}$.

\subsubsection{Effect of Temperature on Proteolytic Activity and Stability}

The temperature effect was determined by performing the protease activity at temperatures from $5^{\circ} \mathrm{C}$ to $90^{\circ} \mathrm{C}$. The temperature stability was measured by keeping the enzyme extract in the absence of substrate at temperatures from $5^{\circ} \mathrm{C}$ to $90^{\circ} \mathrm{C}$. Aliquots were rapidly cooled $\pm 25^{\circ} \mathrm{C}$, to ensure efficient refolding of the molecules of the enzyme optionally reversibly inactivated, were withdraw every $60 \mathrm{~min}$ to determine the residual activity at different times $(0,60,120$ and $180 \mathrm{~min})$.

\subsubsection{Effects of Metal Ions on the Proteolytic Activity}

Protease activity was assessed in the presence of ions, as inhibitors or activators of activity. The effect of ionic solutions was evaluated at concentrations of $5 \mathrm{mM}$ and $10 \mathrm{mM}$ in $0.2 \mathrm{M}$ Tris- $\mathrm{HCl} \mathrm{pH} \mathrm{7.2.} \mathrm{The} \mathrm{following} \mathrm{ions} \mathrm{were} \mathrm{used:} \mathrm{ZnSO}_{4} \cdot 7 \mathrm{H}_{2} \mathrm{O}, \mathrm{MgSO}_{4} \cdot 7 \mathrm{H}_{2} \mathrm{O}$, $\mathrm{CuSO}_{4} \cdot 5 \mathrm{H}_{2} \mathrm{O}, \mathrm{FeSO}_{4} \cdot 7 \mathrm{H}_{2} \mathrm{O}, \mathrm{CaCl}_{2}, \mathrm{HgCl}_{2} \cdot 4 \mathrm{H}_{2} \mathrm{O}, \mathrm{KCl}$ and $\mathrm{NaCl}$, and incubated at $28^{\circ} \mathrm{C}$ for $30 \mathrm{~min}$. The enzyme activity without ions was considered as control (100\%) and the Protease activity was determined by the method described in 2.4 Section.

\subsubsection{Effects of Inhibitors on Proteolytic Activity}

To evaluate the effect of inhibitors on enzyme activity, the crude extract was exposed to the following protease inhibitors: Phenylmethylsulfonyl fluoride $(10 \mathrm{mM}), 2$-mercaptoethanol $(10 \mathrm{mM}))$, Ethylenediaminetetraacetic acid $(10 \mathrm{mM})$, Pepstatin A (1 mM) and Iodoacetic acid $(10 \mathrm{mM})$ and were performed at $25^{\circ} \mathrm{C}$ for $30 \mathrm{~min}$. The enzyme activity without inhibitor was considered as control (100\%). 


\subsection{Sodium Dodecyl Sulphate-Polyacrylamide Gel Electrophoresis (SDS-PAGE)}

SDS-PAGE was carried out using a $12 \%$ polyacrylamide running gel according to the method of Laemmli [18]. The protein molecular markers were phosphorylase b (97.0 $\mathrm{kDa})$, albumin $(66.0 \mathrm{kDa})$, ovalbumin $(45.0 \mathrm{kDa})$, carbonic anhydrase $(30.0 \mathrm{kDa})$, trypsin inhibitor $(20.1 \mathrm{kDa})$ and $\alpha$-lactalbumin $(14.4 \mathrm{kDa})$. Protein bands were detected by staining with Coomassie brilliant blue R-250 and protein molecular markers were detected by silver. SDS-PAGE was distained with a solution of methanol, acetic acid and water.

\subsection{Zymogram}

The proteolytic activity of the enzyme band was confirmed by zymogram analysis. To prepare a gelatin zymogram with $0.1 \%$ gelatin as substrate incorporated in the gel. Gels were loaded with $10 \mu \mathrm{L}$ of concentrated supernatant, subject to electrophoresis at a constant current of $100 \mathrm{~V}$ at $25^{\circ} \mathrm{C}$ and incubated for $30 \mathrm{~min}$ at room temperature with $2 \%(\mathrm{v} / \mathrm{v})$ Triton $\mathrm{X}-100$ and for $48 \mathrm{~h}$ at $37^{\circ} \mathrm{C}$ in $50 \mathrm{mMTris}-\mathrm{HCl}$ buffer and $15 \mathrm{mM}$ $\mathrm{CaCl}_{2}, \mathrm{pH}$ 7.5. To azocasein zymogram with $0.1 \%$ azocasein as substrate incorporated in the gel. The azocasein was dissolved in Tris- $\mathrm{HCl} \mathrm{pH} \mathrm{8.8,} \mathrm{keeping} \mathrm{the} \mathrm{same} \mathrm{concen-}$ trations for performing the gelatin zymogram. Gels were finally stained and destained as described in the previous section.

\section{Results and Discussion}

\subsection{Screening of Aspergillus for Protease Production}

Thirty-four strains of Aspergillus were evaluated among soy-based medium (MS-2) showed that all activities between 0.43 and $34.13 \mathrm{U} / \mathrm{mL}$ (Table 1 ).

Table 1. Microorganisms of the aspergillus genus and their proteolytic activities after $72 \mathrm{~h}$ of submerged fermentation in soybean flour medium (ms-2).

\begin{tabular}{ccccc}
\hline URM & Microorganisms & $\mathrm{PA}^{*}(\mathrm{U} / \mathrm{mL})$ & $\mathrm{URM}$ & Microorganisms \\
\hline 224 & Aspergillus terreus & 3.27 & 5741 & Aspergillus niger \\
269 & Aspergillus heteromorphus & 15.77 & 5756 & Aspergillus niger \\
1546 & Aspergillus carbonarius & 1.43 & 5774 & Aspergillus sydowii \\
3266 & Aspergillus tamarii & 3.77 & 5778 & Aspergillus parasiticus \\
3818 & Aspergillus carbonarius & 0.97 & 5787 & Aspergillus parasiticus \\
3856 & Aspergillus niger & 2.70 & 5791 & Aspergillus flavus \\
3916 & Aspergillus japonicas & 1.93 & 5792 & Aspergillus sclerotiorum \\
4634 & Aspergillus tamarii & 29.90 & 5793 & Aspergillus flavus \\
4658 & Aspergillus terreus & 7.77 & 5794 & Aspergillus flavus \\
4924 & Aspergillus phoenicis & 10.13 & 5827 & Aspergillus melleus \\
4953 & Aspergillus aculeatus & 1.43 & 5837 & Aspergillus niger \\
5093 & Aspergillus terreus & 1.37 & 5838 & Aspergillus niger \\
5182 & Aspergillus caespitosus & 0.43 & 5860 & Aspergillus sydowii \\
5218 & Aspergillus niger & 0.73 & 5863 & Aspergillus niger \\
5242 & Aspergillus japonicas & 3.73 & 5864 & Aspergillus terreus \\
5701 & Aspergillus versicolor & 8.67 & 5870 & Aspergillus niveus \\
5740 & Aspergillus flavus & 34.13 & 5895 & Aspergillus terreus var. aureus \\
\hline
\end{tabular}

${ }^{*}$ PA-Protease activity. 
Aspergillus flavus showed protease activity of $34.13 \mathrm{U} / \mathrm{mL}$. However, this microorganism is known as mycotoxin producer such as aflatoxin B1 and B2, G1 and G2 and cyclopiazonic acid, being unfeasible its application in some biotechnological processes such as the food industry [19] [20]. Electrophoretic analysis and x-rays were used for the detection of aflatoxins in Aspergillus flavus isolates from seeds Cassi tora (L.), confirming the presence of mycotoxin [21]. The enzyme extract from Aspergillus tamarii URM4634 was selected (protease activity $29.90 \mathrm{U} / \mathrm{mL}$ and specific activity 498.33 $\mathrm{U} / \mathrm{mg})$.

Aspergillus tamarii URM4634 was also selected because the high protease production compared to other microorganisms and the absence of release of aflatoxins. The constituents of CMA have an effect on fluorescent pigment production in coconut culture [22]. Our findings showed that aflatoxins were not detected CMA on the presence of fluorescence ring. In ammonium hydroxide vapor test, Aspergillus tamarii URM4634 do not produced pinkish pigmentation on the reverse of colonies. Yazdani et al. [22] studied aflatoxin production from Aspergillus tamarii using two chromatography techniques (TLC and HPLC), CMA test and ammonium test not being found aflatoxins, in agreement to this study.

The study findings corroborate with the literature, emphasizing the potential of $A s$ pergillus genus as a protease producer. Boer and Peralta [23] evaluated the proteases production by various soil fungi of Aspergillus genus. Several fungi used by them, showed protease production from Aspergillus tamarii by submerged fermentation technique, obtaining the maximum protease activity of $63.4 \mathrm{U} / \mathrm{mL}$ after $120 \mathrm{~h}$.

In another study performed by Dhandapani et al. [24] a selection of microorganisms isolated from leather tannery, Aspergillus tamarii was selected as the best producer of alkaline protease in a bioreactor, showing protease activity of $1.61 \mathrm{U} / \mathrm{mL}$.

In the second step of screening, wheat grains, Canadian lentils, amaranth flakes, soybean grains, nuggets sunflower, oat bran and wheat bran were used as substrates for solid-state fermentation and evaluation of $A$. tamarii URM4634 growth into the agroindustrial by-products. Filamentous fungi are the most widely microorganisms used in SSF because of their ability to grow in solid substrates even in the absence of free water [8].

The best agroindustrial substrate for protease production in SSF was wheat bran and showed protease activity of $340 \mathrm{U} / \mathrm{mL}$ (Figure 1). Zanine et al. [25] evaluated the wheat bran as substrate and observed great potential for moisture, as well as improved fermentation profile due to reduction of dry matter loss, and composed primarily of insoluble fibers and aleurone cells of germ, avoiding the drying process in solid-state fermentation. Study by Anandan et al. [26] has shown that when added wheat bran in media containing glucose and other nutrients sources, such as citrate, maltose, lactose and sucrose, Aspergillus tamarii NRRL20818showed excellent proteolytic activities. In another study with Aspergillus oryzae MTCC5341 and using rice bran and wheat bran as substrates, the last one increased the proteolytic activity of $25.6 \%$ compared with rice bran [7]. 


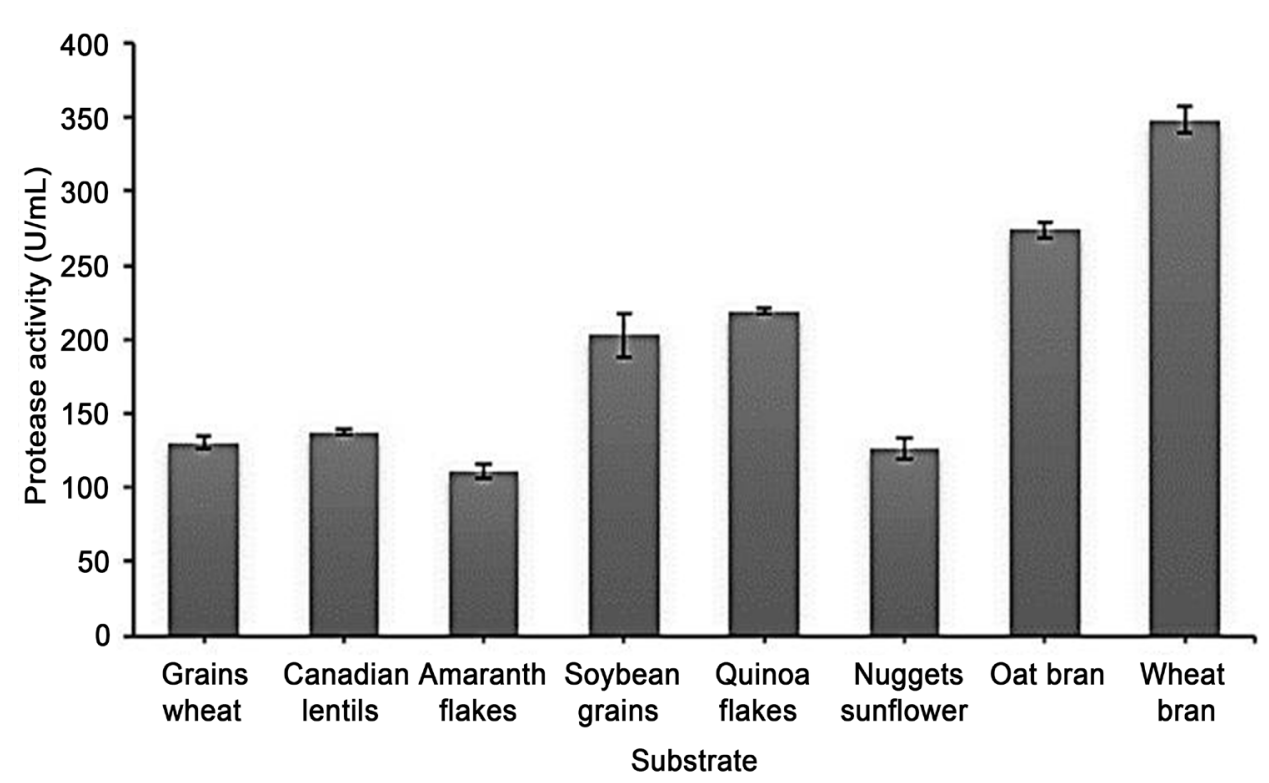

Figure 1. Protease activity from Aspergillus tamarii URM4634 in solid-state fermentation in different agroindustrial substrates.

\subsection{Full Factorial Design for Protease Production from A. tamarii URM4634 by Solid-State Fermentation}

The best value of the protease activity was $404.67 \mathrm{U} / \mathrm{mL}$, obtained from the average of the results of the central points $\left(5 \mathrm{~g}\right.$ wheat bran, $40 \%$ moisture at $30^{\circ} \mathrm{C}$ ) (Table 2$)$ in 72 $\mathrm{h}$ of fermentation.

The analysis of the effects (Table 3 ) showed that only one variable had statistically significant effect, since the value of estimated effect was above the significance level ( $\mathrm{p}<$ $0.05)$. For protease activity, the variable that showed significant effect on enzyme production was temperature, with negative effect, from $72 \mathrm{~h}$ of fermentation, indicating that decreasing temperature could enhance the protease production by $A$. tamarii URM4634.

Nascimento et al. [27] when studying the effect of the variables substrate, moisture and temperature to produce a protease from Mucor subtilissimus UCP1262 obtained the protease activity $48.33 \mathrm{U} / \mathrm{mL}$ in Solid-state Fermentation containing $3 \mathrm{~g}$ of wheat bran, $50 \%$ moisture at $30^{\circ} \mathrm{C}$. The amount of substrate and moisture showed no effect on the production of proteases by Brevibacterium linens DSM 20158 were obtained at $30^{\circ} \mathrm{C}$ [28]. Both of works showed that temperature at $30^{\circ} \mathrm{C}$ was responsible for the higher activity values. For the temperature is an important factor in the growth of the microorganism and proteases production.

The best condition was also tested for specific proteolytic activities such as collagenase $(243.0 \mathrm{U} / \mathrm{mL})$ and keratinase $(19.1 \mathrm{U} / \mathrm{mL})$, due to their biotechnological potential. Lima et al., [29] showed that a collagenase serine protease from Penicillium aurantiogriseum URM4622 exhibited activity of $164 \mathrm{U} / \mathrm{mL}$. Siqueira et al. [30] studied a keratinase produced by solid-state fermentation of Aspergillus terreus exhibited activity of $677 \mathrm{U} / \mathrm{mL}$. 
Table 2. Results of protease production from Aspergillus tamarii URM4634 by solid-state fermentation performed according to the $2^{3}$ full factorial design.

\begin{tabular}{ccccc}
\hline Runs & Substrate (g) & Moisture (\%) & Temperature $\left.{ }^{\circ} \mathrm{C}\right)$ & PA* $^{*}(\mathrm{U} / \mathrm{mL})$ \\
\hline 1 & 3 & 30 & 25 & 353.83 \\
2 & 7 & 30 & 25 & 337.00 \\
3 & 3 & 50 & 25 & 353.67 \\
4 & 7 & 50 & 25 & 383.17 \\
5 & 3 & 30 & 35 & 312.50 \\
6 & 7 & 30 & 35 & 235.17 \\
7 & 3 & 50 & 35 & 251.17 \\
8 & 7 & 50 & 35 & 263.67 \\
$9(\mathrm{C})$ & 5 & 40 & 30 & 399.17 \\
$10(\mathrm{C})$ & 5 & 40 & 30 & 404.67 \\
$11(\mathrm{C})$ & 5 & 40 & 30 & 397.67 \\
$12(\mathrm{C})$ & 5 & 40 & 30 & 404.17 \\
\hline
\end{tabular}

${ }^{*}$ PA-Protease Activity. (C)-Central points.

Table 3. Effect estimates of $2^{3}$ full factorial design for protease production from Aspergillus tamarii URM4634 by solid-state fermentation.

\begin{tabular}{cc}
\hline Factors & Effects \\
Substrate & -0.78 \\
Moisture & 0.19 \\
Temperature & $-5.52^{\star}$ \\
$1 \times 2$ & 2.06 \\
$1 \times 3$ & -1.17 \\
$2 \times 3$ & -1.19 \\
$1 \times 2 \times 3$ & 0.65 \\
\hline
\end{tabular}

${ }^{*}$ Statistically significant at $95 \%$ confidence level $(\mathrm{p}<0.05)$.

\subsection{Determination of the Microorganism Biomass}

The evolution of fungal cellular growth in wheat bran was estimated by glucosamine level during $196 \mathrm{~h}$ of cultivation. A. tamarii URM4634 exhibited a maximum glucosamine level of $119.33 \mathrm{mg} / \mathrm{g} \pm 4.8$, after $96 \mathrm{~h}$ cultivation (Figure 2 ). The protease production showed a good correlation with the glucosamine content, resulting in activity of $530.16 \mathrm{U} / \mathrm{mL} \pm 0.02$, after $72 \mathrm{~h}$ cultivation, indicating an increase of the protease production with the increase of the biomass (glucosamine level). Incubation beyond this period did not result any further increase in biomass concentration but resulted in a slight decrease in enzyme level.

Similar values found in this study was also reported by Castro et al. [8] when eva- 


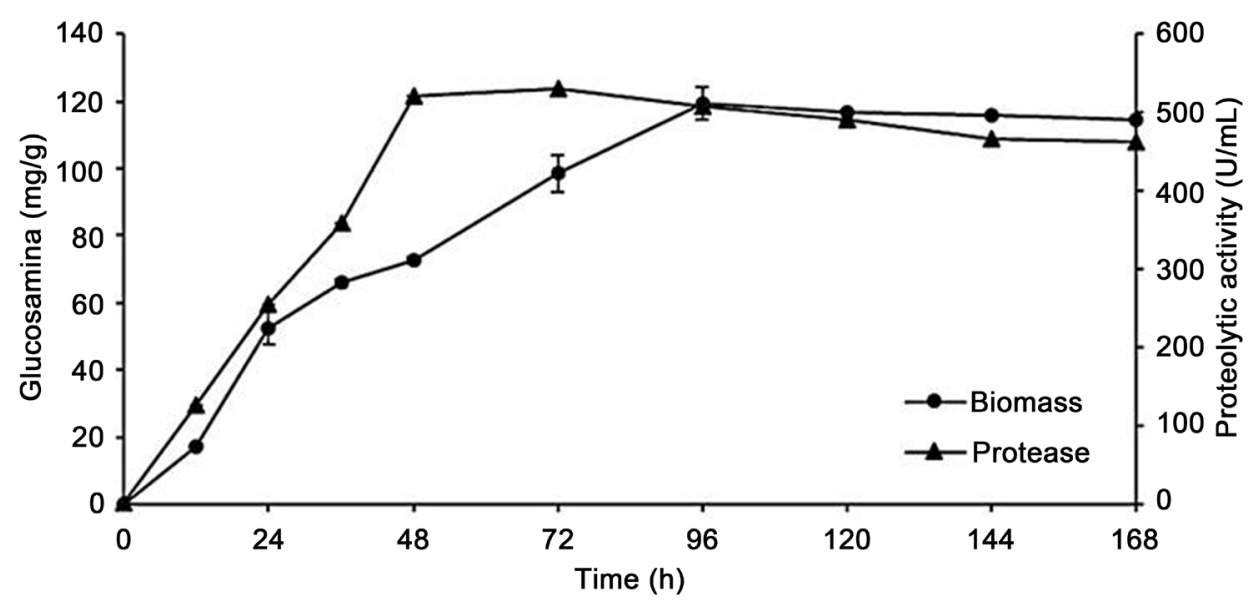

Figure 2. Biomass estimation (glucosamine) and proteolytic activity from A. tamarii URM4634 in wheat bran solid-state fermentation.

luated different agroindustrial by-products such as wheat bran, soybean meal and cotton seed meal, showed glucosamine levels of $90.33 \mathrm{mg} / \mathrm{g}$ when grown in wheat bran, after $96 \mathrm{~h}$ of cultivation. Ramachandran et al. [31] exhibited $57 \mathrm{mg} / \mathrm{g}$ of biomass after 72 $\mathrm{h}$ of cultivation in wheat bran.

\subsection{Kinetic Parameters of the Protease Activity}

The $\mathrm{K}_{\mathrm{M}}$ and $V \max$ values were $18.7 \mathrm{mg} / \mathrm{mL}$ and $28.57 \mathrm{mg} / \mathrm{mL} / \mathrm{min}$, respectively. $\mathrm{K}_{\mathrm{M}}$ was related to the affinity of the enzyme toward azocasein substrate. Lineweaver-Burk plot of initial velocity of the extracellular protease from Aspergillus tamarii URM4634 is shown in Figure 3. The $\mathrm{K}_{\mathrm{M}}=5.4 \mathrm{mg} / \mathrm{mL}$ were recorded for the detergent-compatible protease from Aspergillus terreus [32]. Ha et al. [33] has reported a commercial protease with $\mathrm{K}_{\mathrm{M}}=24.9 \mathrm{mg} / \mathrm{mL}$ the fungus $31 \mathrm{~K}$ in the degradation of meat proteins. Omolara et al. [34] reported a high $\mathrm{K}_{\mathrm{M}}=40.13 \mathrm{mg} / \mathrm{ml}$ from Aspergillus niger, suggesting application in the meat processing industry.

Mushtaq et al. [35] purified and characterized protease from Rhizopus oryzae with $\mathrm{K}_{\mathrm{M}}=7.0 \mathrm{mg} / \mathrm{mL}$ for application in detergents industry. The characterization of the kinetic parameters of an alkaline protease produced by Penicillium nalgiovense [36] showed $\mathrm{K}_{\mathrm{M}} 18$ times smaller and Vmax 28 times lower than present work, which presented to $\mathrm{K}_{\mathrm{M}}=1.152 \mathrm{mg} / \mathrm{mL}$ and $\mathrm{Vmax}=0.827 \mathrm{mg} / \mathrm{mL} / \mathrm{min}$, respectively. According to what has been reported, $\mathrm{K}_{\mathrm{M}}$ greater values of $5 \mathrm{mg} / \mathrm{mL}$ can be used in meat processing as well as detergents industries. However, it is known that the smaller values of $K_{M}$ greater are the affinity of the enzyme for the substrate.

\subsection{The Effect of pH and Stability of Protease}

Results of pH effect on enzyme activity and stability can be observed in Figure 4. The optimum $\mathrm{pH}$ for protease activity $(417.67 \mathrm{U} / \mathrm{mL})$ was obtained at $\mathrm{pH} 8.0(0.2 \mathrm{M}$ Tris$\mathrm{HCl})$. The same optimum $\mathrm{pH}(8.0)$ was found for alkaline protease from Aspergillus nidulans HA-10 [37]. Similar research with the protease from thermophilic fungus 


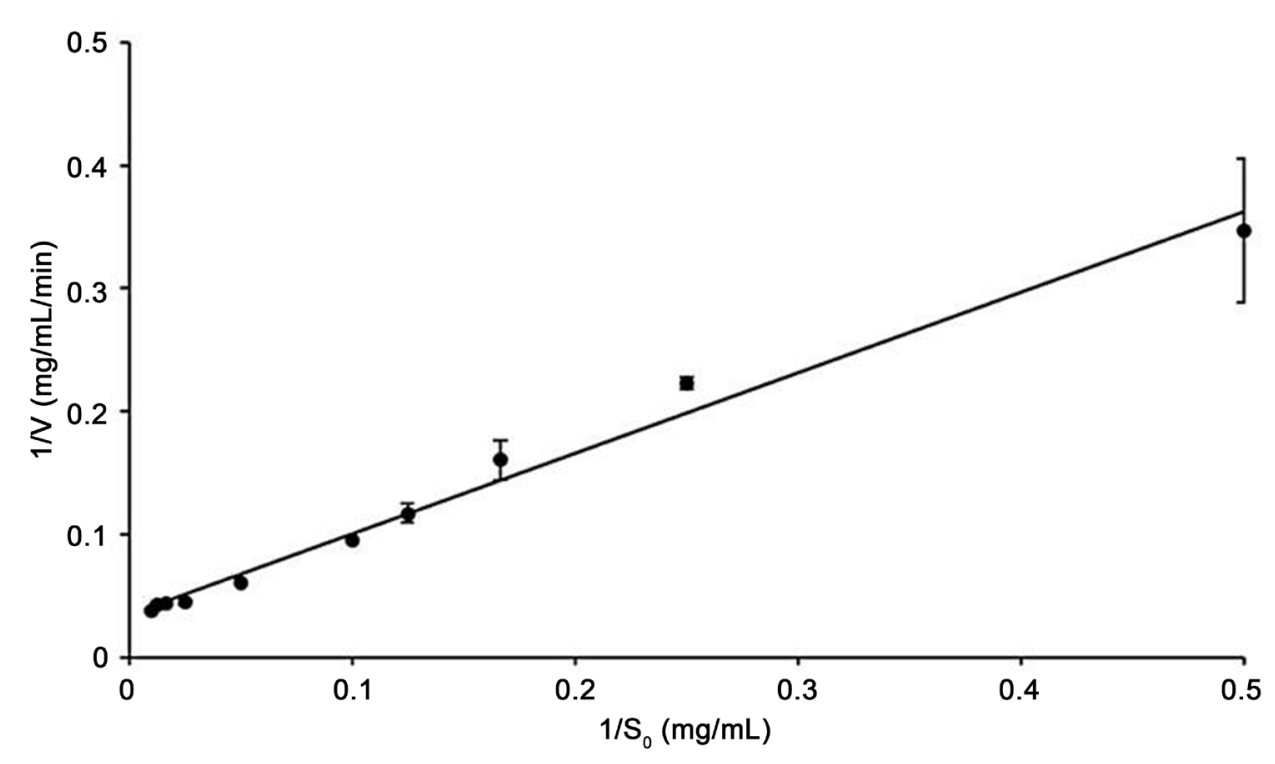

Figure 3. Curve double reciprocal Lineweaver-Burk extracellular protease from Aspergillus tamarii URM4634 using azocasein as a substrate $\left(\mathrm{R}^{2}=0.99\right)$.

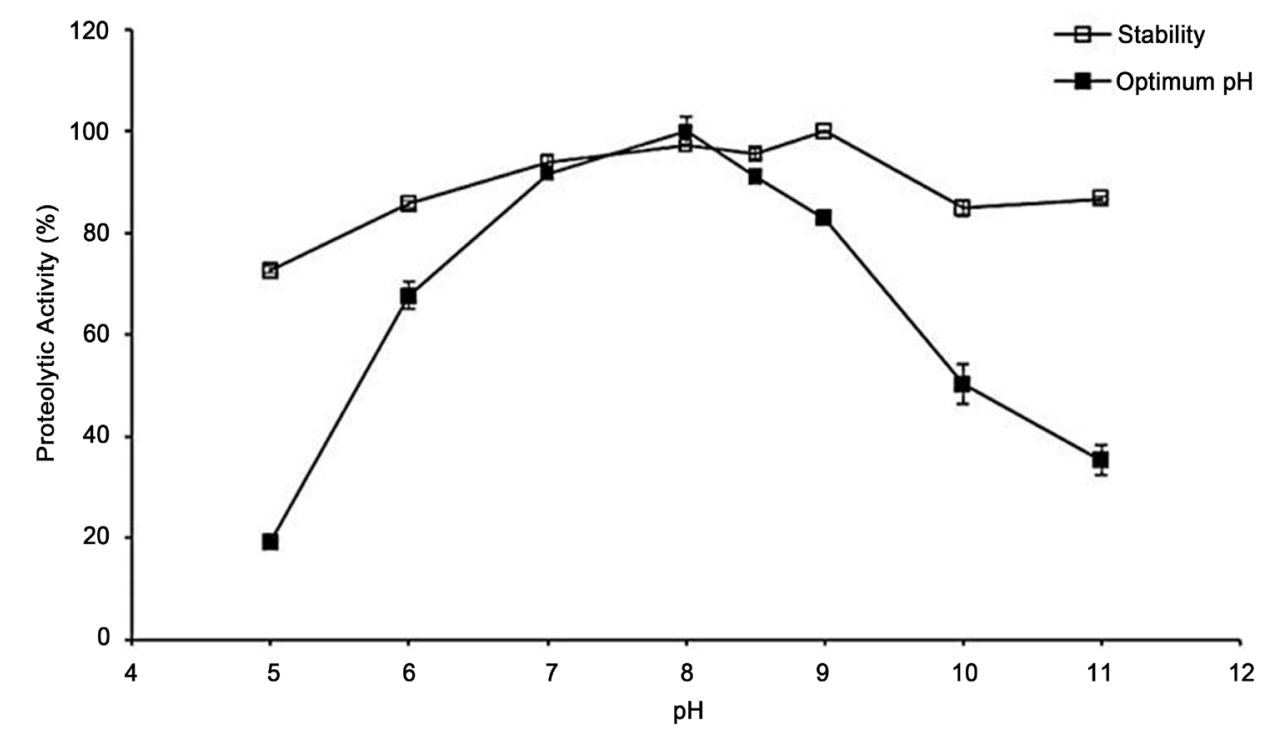

Figure 4. Curve optimum $\mathrm{pH}$ and stability of the protease produced by Aspergillus tamarii URM4634 in different buffers for $24 \mathrm{~h}$ the reaction.

Myceliophthora sp., showed optimum pH 9.0 in SSF. On the other hand, the same protease and microorganism grown in submerged fermentation had its optimum $\mathrm{pH} 7.0$ [2], suggesting a different protease expression in both fermentation techniques.

The enzyme showed $91.66 \%$ and $91.18 \%$ of its activity relative to the $\mathrm{pH} 7.0$ and 8.5 in same buffer. The protease retained its activity of $82.88 \%$ and $50.28 \%$ in $0.2 \mathrm{M}$ Glycine- $\mathrm{NaOH}$ buffer $\mathrm{pH} 9.0$ and 10.0, respectively. The results show that the enzyme was stable over a wide $\mathrm{pH}$ range $(6.0-11.0)$.

The $\mathrm{pH}$ stability of the enzyme is important for enzymatic characterization, before 
being marketed. The protease produced by Aspergillus tamarii URM4634 was stable at all $\mathrm{pH}$ values tested, showing $70 \%$ residual activity at $\mathrm{pH} 5.0$ and $86.7 \%$ in $\mathrm{pH} 11.0$ until $24 \mathrm{~h}$. This $\mathrm{pH}$ stability of the protease of $A$. tamarii URM4634 showed potential for possible industrial applications. Protease with alkaline properties can be used in leather, detergents and pharmaceutical industry [2].

\subsection{Optimum Temperature and Stability of Protease}

The temperature is one of the most critical parameters to be controlled in bioprocesses [38]. The optimum temperature of the protease was $40^{\circ} \mathrm{C}$ (Figure 5). At $25^{\circ} \mathrm{C}$, the enzyme showed relative activity of $78.25 \%$ and $24.93 \%$ at $80^{\circ} \mathrm{C}$. The activity was completely lost when exposed to $90^{\circ} \mathrm{C}$.

Yadav et al. [39] found the same optimum temperature for characterization of alkaline protease from Aspergillus flavus. In agreement to this study, Kranthi et al. [40] have reported optimum temperature for characterization of proteases from Aspergillus flavus using different oil seeds as substrate. However, an optimum temperature of $60^{\circ} \mathrm{C}$ was reported in the characterization of protease from Aspergillus fumigatus and the protease showed $60 \%$ residual activity at $64^{\circ} \mathrm{C}$ [41]. The protease produced by Aspergillus tamarii URM4634 showed more than $68 \%$ residual activity when compared to the same temperature as described by Hernández-Martínez et al. [41]. The protease was stable at $40^{\circ} \mathrm{C}$, decreasing sharply above $50^{\circ} \mathrm{C}$ and completely losing the activity to $90^{\circ} \mathrm{C}$ after $180 \mathrm{~min}$.

\subsection{Effect of Metal Ions on the Proteolytic Activity}

Influences of ionic solutions were evaluated at concentrations of $5 \mathrm{mM}$ and $10 \mathrm{mM}$ (Table 4). The enzyme activity was not affected by ion $\mathrm{K}^{+}$in both concentrations is important to emphasize the role of $\mathrm{K}^{+}$ions in cell physiology. Furthermore, the enzyme activity was stimulated in the presence of $\mathrm{Ca}^{2+}, \mathrm{Zn}^{2+}, \mathrm{Na}^{+}$and $\mathrm{Mg}^{2+}$ at a concentration of

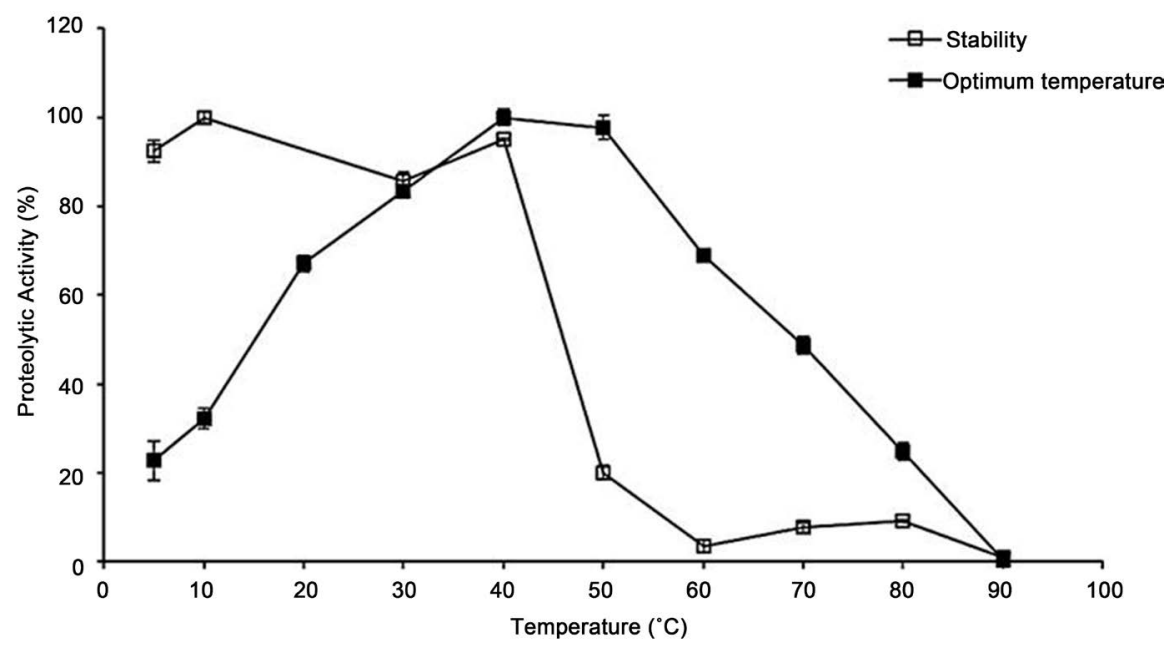

Figure 5. Curve optimum temperature and stability of protease produced by Aspergillus tamarii URM4634 at different temperatures at $180 \mathrm{~min}$. 
Table 4. Effect of metal ions on protease activity from Aspergillus tamarii URM4634.

\begin{tabular}{ccc}
\hline \multirow{2}{*}{ Metal ions } & $5 \mathrm{mM}$ & $10 \mathrm{mM}$ \\
\cline { 2 - 3 } & Residual activity $(\%)$ & Residual activity (\%) \\
\hline $\mathrm{K}^{+}$ & $100.0 \pm 2.12$ & $100.0 \pm 2.12$ \\
$\mathrm{Ca}^{2+}$ & $100.0 \pm 2.45$ & $100.0 \pm 1.19$ \\
$\mathrm{Zn}^{2+}$ & $100.0 \pm 2.01$ & $112.88 \pm 0.24$ \\
$\mathrm{Mg}^{2+}$ & $100.0 \pm 1.13$ & $111.36 \pm 0.40$ \\
$\mathrm{Na}^{+}$ & $106.89 \pm 1.89$ & $116.39 \pm 1.67$ \\
$\mathrm{Fe}^{2+}$ & $115.86 \pm 1.90$ & $114.98 \pm 1.66$ \\
$\mathrm{Hg}^{2+}$ & $115.82 \pm 1.86$ & $93.95 \pm 0.23$ \\
$\mathrm{Cu}^{2+}$ & $91.21 \pm 1.27$ & $77.31 \pm 0.83$ \\
\hline
\end{tabular}

$10 \mathrm{mM}$. However, the protease was inhibited by $\mathrm{Hg}^{2+}$ (22.69\%) and $\mathrm{Cu}^{2+}(33.98 \%)$. Similarly results were obtained for alkaline protease produced by Aspergillus flavus [40] and Bacillus sp. P7 [42] where the $\mathrm{Cu}^{2+}$ ion showed the inhibition 26.7\%. The effects of $\mathrm{Ca}^{2+}$ and $\mathrm{Mg}^{2+}$ in alkaline proteases from Bacillus firmus CAS7 [4] have been reported as stimulators, and $\mathrm{K}^{+}$also did not affect the protease from Aspergillus tamarii URM4634. A study of the influence of ions was performed in the activity of an alkaline serine protease from Bacillus licheniformis NCIM-2042, where in the $\mathrm{Zn}^{2+}$ reduced the activity at $8.6 \%$ [43], in contrast to the present study where $\mathrm{Zn}^{2+}$ ion stimulated protease activity at $11.36 \%$.

\subsection{Effect of Inhibitors on Proteolytic Activity}

Enzyme activity was inhibited $65.11 \%$ by $1 \mathrm{mM}$ phenylmethylsulfonyl fluoride (PMSF), classifying the enzyme as a serine protease. It was also slightly inhibited by $10 \mathrm{mM}$ Ethylenediaminetetraacetic acid (EDTA)-metalloprotease inhibitor (71.15\%), $10 \mathrm{mM} 2$ mercaptoethanol-cysteine protease inhibitor (81.62\%), but was not inhibited when subjected to $1 \mu \mathrm{M}$ Pepstatin A-the aspartic protease inhibitor (Table 5). These results allowed the identification of protease crude extract produced by Aspergillus tamarii URM4634 as a serine protease.

The results of this study corroborate with results of the effect of the inhibitor, PMSF, on enzyme activity found by Bhunia et al. [43] indicating that the enzyme belongs to the class of serine proteases, but the effect of EDTA was not observed. Similar results were obtained for alkaline protease produced by Aspergillus flavus that was moderately affected by EDTA, expressing $78 \%$ of its residual activity and completely inhibited by PMSF, indicating that the protease belongs to the class of serine proteases [39]. Several proteases produced by Aspergillus has been characterized (Table 6). The characterization of proteases from Aspergillus tamarii was established according to similar characteristics of this enzyme compared to other proteases. 
Table 5. Effect of inhibitors on the protease activity from Aspergillus tamarii URM4634.

\begin{tabular}{cc}
\hline Inhibitors & Residual activity (\%) \\
\hline Control & $100.0 \pm 2.58$ \\
EDTA & $71.15 \pm 0.94$ \\
PMSF & $34.89 \pm 2.00$ \\
2-Mercaptaethanol & $81.62 \pm 0.76$ \\
Idoacetic acid & $94.33 \pm 2.00$ \\
Pepstatin A & $100.0 \pm 0.16$ \\
\hline
\end{tabular}

Table 6. Biochemical properties of proteases from Aspergillus tamarii URM4634 and proteases from Aspergillus.

\begin{tabular}{ccclc}
\hline Microorganisms & $\begin{array}{c}\text { Optimum } \\
\text { temperature }\end{array}$ & $\begin{array}{c}\text { Optimum } \\
\mathrm{pH}\end{array}$ & Type catalytic & References \\
\hline Aspergillus tamarii & $40^{\circ} \mathrm{C}$ & 8.0 & Serine protease & This work \\
Aspergillus tamarii & $\mathrm{NA}$ & 9.0 & Serine protease & {$[26]$} \\
Aspergillus parasiticus & $50^{\circ} \mathrm{C}$ & 7.0 & Serine protease & {$[44]$} \\
Aspergillus flavus & $45^{\circ} \mathrm{C}$ & 7.5 & Serine protease & {$[40]$} \\
Aspergillus niger & $\mathrm{NA}$ & 9.0 & Metalloproteases & {$[45]$} \\
Aspergillus niger & $60^{\circ} \mathrm{C}$ & 8.0 & Metalloproteases & {$[46]$} \\
Aspergillus niger & $40^{\circ} \mathrm{C}$ & 3.5 & Aspartic protease & {$[47]$} \\
Aspergillus carbonarius & $40^{\circ} \mathrm{C}$ & 3.0 & Cysteine protease & {$[48]$} \\
\hline
\end{tabular}

NA $=$ Not Available

\subsection{SDS-PAGE and Zymogram}

SDS-PAGE and Zymogram were applied to verify the electrophoretic profile of the enzyme extract by $A$. tamarii URM4634 (Figure 6). The obtained profile showed nine proteins with molecular weights of $18.2 \mathrm{kDa}$ to $98.8 \mathrm{kDa}$. The nature of the proteolytic enzyme was also confirmed by zymogram with two different substrates: Gelatin (ZG) and Azocasein (ZA), using both substrates a hydrolyzed band appeared as a white band that corresponded to the position of the protease in the gel. The crude extract was used without purification, so the activity observed in the white band probably corresponded to more than one enzyme.

\section{Conclusion}

The results obtained in this study showed that the high levels of protease production by Aspergillus tamarii URM4634 could be achieved by adjusting the parameters, as the amount of substrate ( $5 \mathrm{~g}$ wheat bran), moisture $(40 \%)$ and temperature $\left(30^{\circ} \mathrm{C}\right)$. The effect of temperature on the fermentation process showed a negative effect as an important factor, inducing the best protease production at $72 \mathrm{~h}$. The biochemical characterization showed the optimum $\mathrm{pH} 8.0$ and $40^{\circ} \mathrm{C}$ and $\mathrm{pH}$ stability $(5.0$ - 11.0) and thermostability $\left(10^{\circ} \mathrm{C}-40^{\circ} \mathrm{C}\right)$. The enzyme is a serine protease and showed collagenolytic and keratinolytic activities. The protease produced by $A$. tamarii URM4634 showed enzymatic characteristics that are suitable for using in industrial applications as leather 


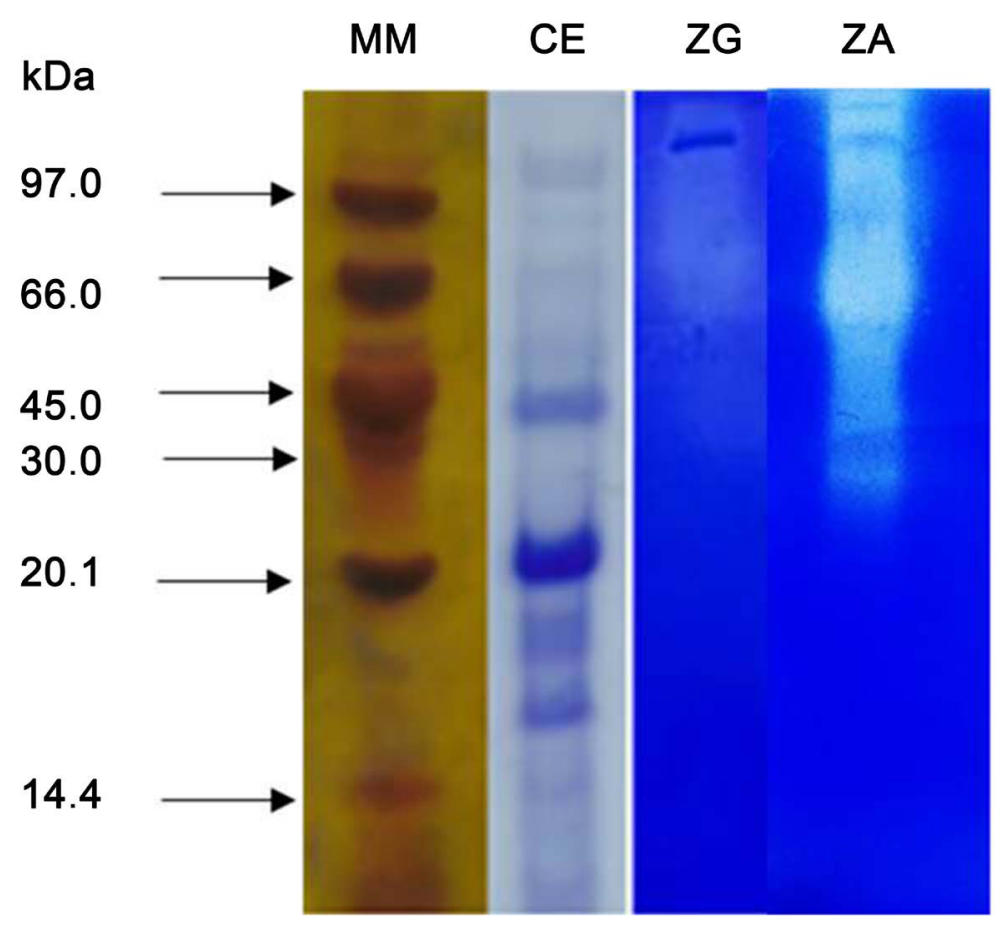

Figure 6. Molecular weight determination of protease by Aspergillus tamarii URM4634 using SDS-PAGE (12\%) and zymogram analysis of protease. MM: protein molecular weight standard; CE: crude extract; ZG: protease gelatin zymogram; ZA: protease azocasein zymogram.

processing and food industries, with low cost using wheat bran agroindustrial wastes as substrate.

\section{Acknowledgements}

The authors are greateful to FACEPE (Foundation for Science and Technology of the State of Pernambuco, Brazil) process IBPG-0257-5.07/14 for the scholarship to the first author, $\mathrm{CNPq}$ (National Council for Scientific and Technological Development, Brazil) and CAPES (National Council for the Improvement of Higher Education, Brazil) for the financial support.

\section{References}

[1] Vishwanatha, K.S., Rao. A.G.A. and Singh, S.A. (2010) Acid Protease Production by SolidState Fermentation Using Aspergillus oryzae MTCC 5341: Optimization of Process Parameters. Journal of Industrial Microbiology \& Biotechnology, 37, 129-138.

https://doi.org/10.1007/s10295-009-0654-4

[2] Zanphorlin, L.M., Facchini, F.D.A., Vasconcelos, F., Bonugli-Santos, R.C., Rodrigues, A. and Sette, L.D. (2010) Production, Partial Characterization, and Immobilization in Alginate Beads of an Alkaline Protease from a New Thermophilic Fungus Myceliophthora sp. The Journal of Microbiology, 48, 331-336. https://doi.org/10.1007/s12275-010-9269-8

[3] Padmapriya, B., Rajeswari, T., Nandita, R. and Raj F. (2012) Production and Purification of Alkaline Serine Protease from Marine Bacillus Species and Its Application in Detergent In- 
dustry. European Journal of Applied Sciences, 4, 21-26.

[4] Annamalai, N., Rajeswari, M.V.,Sahu, S.K. and Balasubramanian, T. (2014) Purification and Characterization of Solvent Stable, Alkaline Protease from Bacillus firmus CAS 7 by Microbial Conversion of Marine Wastes and Molecular Mechanism Underlying Solvent Stability. Process Biochemistry, 49, 1012-1019.

https://doi.org/10.1016/j.procbio.2014.03.007

[5] Novelli, P.K., Barros, M.M. and Fleuri, L.F. (2016) Novel Inexpensive Fungi Proteases: Production by Solid State Fermentation and Characterization. Food Chemistry, 198, 119-124. https://doi.org/10.1016/j.foodchem.2015.11.089

[6] Mukherjee, A.K., Adhikari, H. and Rai, S.K. (2008) Production of Alkaline Protease by a Thermophilic Bacillus subtilis under Solid-State Fermentation (SSF) Condition Using Imperata cylindrica Grass and Potato Peel as Low-Cost Medium: Characterization and Application of Enzyme in Detergent Formulation. Biochemical Engineering Journal, 39, 353-361. https://doi.org/10.1016/j.bej.2007.09.017

[7] Vishwanatha, K., Appurao, A. and Singh, S. (2009) Characterisation of Acid Protease Expressed from Aspergillus oryzae MTCC 5341. Food Chemistry, 114, 402-407.

https://doi.org/10.1016/j.foodchem.2008.09.070

[8] de Castro, R.J.S., Nishide, T.G. and Sato, H.H. (2014) Production and Biochemical Properties of Proteases Secreted by Aspergillus niger under Solid State Fermentation in Response to Different Agroindustrial Substrates. Biocatalysis and Agricultural Biotechnology, 3, 236245. https://doi.org/10.1016/j.bcab.2014.06.001

[9] Sherf, A.F. (1943) A Method for Maintaining Phytomonas sepedonica in Culture for Long Periods without Transfer. Phytopathology, 33, 330-332.

[10] Porto, A.L.F., Campos-Takaki, G. and Filho, J.L.L. (1996) Effects of Culture Conditions on Protease Production by Streptomyces clavuligerus Growing on Soy Bean Flour Medium. Applied Biochemistry and Biotechnology, 60, 115-122. https://doi.org/10.1007/BF02788066

[11] Stasoft, I. (2008) Statistica (Data Analysis Software Systems) Version 8.0.

[12] Ginther, C.L. (1979) Sporulation and the Production of Serine Protease and Cephamycin C by Streptomyces lactamdurans. Antimicrobial Agents and Chemotherapy, 15, 522-526. https://doi.org/10.1128/AAC.15.4.522

[13] Chavira, R., Burnett, T.J. and Hageman, J.H. (1984) Assaying Proteinases with Azocoll. Analytical Biochemistry, 136, 446-450. https://doi.org/10.1016/0003-2697(84)90242-2

[14] Anbu, P., Gopinath, S.C.B., Hilda, A., Lakshmipriya, T. and Annadurai, G. (2007) Optimization of Extracellular Keratinase Production by Poultry Farm Isolate Scopulariopsis brevicaulis. Bioresource Technology, 98, 1298-1303.

https://doi.org/10.1016/j.biortech.2006.05.047

[15] Lin, M.T. and Dianese, J.C.A. (1976) A Coconut-Agar Medium for Rapid Detection of Aflatoxin Production by Aspergillus spp. Phytopathology, 66, 1466-1469. https://doi.org/10.1094/Phyto-66-1466

[16] Saito, M. and Machida S. (1999) A Rapid Identification Method for Aflatoxin-Producing Strains of Aspergillus flavus and A. parasiticus by Ammonia Vapor. Mycoscience, 40, 205-208. https://doi.org/10.1007/BF02464300

[17] Kumar, S., Shekhar, M., Khan, A.A. and Sharma, P. (2007) A Rapid Technique for Detection of Toxigenic and Non-Toxigenic Strains of Aspergillus flavus from Maize Grains. Indian Phytopathology, 60, 31-34.

[18] Laemmli, U.K. (1970) Cleavage of Structural Proteins during the Assembly of the Head of Bacteriophage T4. Nature, 227, 680-685. https://doi.org/10.1038/227680a0 
[19] Georgianna, D. (2010) Beyond Aflatoxin: Four Distinct Expression Patterns and Functional Roles Associated with Aspergillus flavus Secondary Metabolism Gene Clusters. Molecular Plant Pathology, 11, 213-226. https://doi.org/10.1111/j.1364-3703.2009.00594.x

[20] Gonçalez, E., Silva, J.L., Reis, T.A., Nakai, V.K., Felicio, J.D. and Corrêa, B. (2013) Produção de aflatoxinas e ácido ciclopiazônico por cepas de Aspergillus flavus isoladas de amendoim. Arquivos do Instituto Biológico, 80, 312-317. https://doi.org/10.1590/S1808-16572013000300008

[21] Tripathi, V.R., Kumar, S. and Garg, S.K. (2011) A Study on Trypsin, Aspergillus flavus and Bacillus sp. Protease Inhibitory Activity in Cassia tora (L.) syn Senna tora (L.) Roxb. Seed extract. BMC Complementary and Alternative Medicine, 11, 56. https://doi.org/10.1186/1472-6882-11-56

[22] Yazdani, D., Abidin, Z. and Tan, Y. (2010) Evaluation of the Detection Techniques of Toxigenic Aspergillus Isolates. African Journal of Biotechnology, 9, 7654-7659.

[23] Boer, C.G. and Peralta, R.M. (2000) Production of Extracellular Protease by Aspergillus tamarii. Journal of Basic Microbiology, 40, 75-81. https://doi.org/10.1002/(SICI)1521-4028(200005)40:2<75::AID-JOBM75>3.0.CO;2-X

[24] Dhandapani, B., Mahadevan, S., Dhilipkumar, S.S., Rajkumar, S. and Mandal, A.B. (2012) Impact of Aeration and Agitation on Metabolic Heat and Protease Secretion of Aspergillus tamarii in a Real-Time Biological Reaction Calorimeter. Applied Microbiology and Biotechnology, 94, 1533-1542. https://doi.org/10.1007/s00253-012-3974-7

[25] Zanine, A.M., Santos, E.M., Ferreira, D.J., Pinto, L.F.B. and Pereira, O.G. (2007) Características fermentativas e composição químico-bromatológica de silagens de capimelefante com ou sem Lactobacillusplantarum e farelo de trigo isoladamente ou em combinação. Ciência Animal Brasileira, 8, 621-628.

[26] Anandan, D., Marmer, W.N. and Dudley, R.L. (2007) Isolation, Characterization and Optimization of Culture Parameters for Production of an Alkaline Protease Isolated from $\mathrm{As}$ pergillus tamarii. Journal of Industrial Microbiology \& Biotechnology, 34, 339-347. https://doi.org/10.1007/s10295-006-0201-5

[27] Nascimento, T.P., Sales, A.E., Porto, C.S., Brandão, R.M.P., Campos-Takaki, G.M., Teixeira, J.A.C., Porto, T.S. and Porto, A.L.F. (2015) Production and Characterization of New Fibrinolytic Protease from Mucor subtillissimus UCP 1262 in Solid-State Fermentation. Advances in Enzyme Research, 3, 81-91. https://doi.org/10.4236/aer.2015.33009

[28] Shabbiri, K., Adnan, A. and Jamil, S. (2012) Medium Optimization of Protease Production by Brevibacterium linens DSM 20158, Using Statistical Approach. Brazilian Journal of Microbiology, 43, 1051-1061. https://doi.org/10.1590/S1517-83822012000300031

[29] Lima, C.A., Filho, J.L.L., Neto, B.B., Converti, A., Cunha, M.G.C. and Porto, A.L.F. (2011) Production and Characterization of a Collagenolytic Serine Proteinase by Penicillium aurantiogriseum URM 4622: A Factorial Study. Biotechnology and Bioprocess Engineering, 16, 549-560. https://doi.org/10.1007/s12257-010-0247-0

[30] Siqueira, A.C.R., Rosa, N.G., Motta, C.M.S. and Cabral, H. (2014) Peptidase with Keratinolytic Activity Secreted by Aspergillus terreus during Solid-State Fermentation. Brazilian Archives of Biology and Technology, 57, 514-522.

https://doi.org/10.1590/S1982-88372014000100008

[31] Ramachandran, S., Roopesh, K., Nampoothiri, K.M., Szakacs, G. and Pandey, A. (2005) Mixed Substrate Fermentation for the Production of Phytase by Rhizopus spp. Using Oilcakes as Substrates. Process Biochemistry, 40, 1749-1754. https://doi.org/10.1016/j.procbio.2004.06.040

[32] Niyonzima, F.N. and More, S.S. (2014) Purification and Characterization of Deter- 
gent-Compatible Protease from Aspergillus terreus gr. 3 Biotech, 5, 61-70.

https://doi.org/10.1007/s13205-014-0200-6

[33] Ha, M., Bekhit, A.E.D., Carne, A. and Hopkins, D.L. (2013) Comparison of the Proteolytic Activities of New Commercially Available Bacterial and Fungal Proteases toward Meat Proteins. Journal of Food Science, 78, C170-C177. https://doi.org/10.1111/1750-3841.12027

[34] Racheal, O.O., Ahmed, A.T.F., Ndigwe, E.V. and Morakinyo, S.D. (2015) Extraction, Purification and Characterization of Protease from Aspergillus niger Isolated from Yam Peels. International Journal of Nutrition and Food Sciences, 4, 125-131. https://doi.org/10.11648/j.ijnfs.20150402.11

[35] Mushtaq, Z., Irfan, M., Nadeem, M., Naz, M. and Syed, Q. (2015) Kinetics Study of Extracellular Detergent Stable Alkaline Protease from Rhizopus oryzae. Brazilian Archives of Biology and Technology, 58, 1-10. https://doi.org/10.1590/S1516-8913201400071

[36] Papagianni, M. and Sergelidis, D. (2014) Purification and Biochemical Characterization of a Novel Alkaline Protease Produced by Penicillium nalgiovense. Applied Biochemistry and Biotechnology, 172, 3926-3938. https://doi.org/10.1007/s12010-014-0824-3

[37] Charles, P., Devanathan, V., Anbu, P., Ponnuswamy, M.N., Kalaichelvan, P.T. and Hur, B.K. (2008) Purification, Characterization and Crystallization of an Extracellular Alkaline Protease from Aspergillus nidulans HA-10. Journal of Basic Microbiology, 48, 347-352. https://doi.org/10.1002/jobm.200800043

[38] Sathya, R., Pradeep, B.V., Angayarkanni, J. and Palaniswamy, M. (2009) Production of Milk Clotting Protease by a Local Isolate of Mucor circinelloides under SSF Using Agro-Industrial Wastes. Biotechnology and Bioprocess Engineering, 14, 788-794. https://doi.org/10.1007/s12257-008-0304-0

[39] Yadav, S.K., Bisht, D. and Darmwal, N.S. (2011) Oxidant and Solvent Stable Alkaline Protease from Aspergillus flavus and Its Characterization. African Journal of Biotechnology, 10, 8630-8640. https://doi.org/10.5897/AJB10.1611

[40] Kranthi, V.S., Rao, D.M. and Jaganmohan, P. (2012) Production of Protease by Aspergillus flavus through Solid State Fermentation Using Different Oil Seed Cakes. International Journal of Microbiology, 3, 12-15.

[41] Hernández-Martínez, R., Gutiérrez-Sánchez, G., Bergmann, C.W., Loera-Corral, O., Rojo-Domínguez, A., Huerta-Ochoa, S., Regalado-González, C. and Prado-Barragán, L.A. (2011) Purification and Characterization of a Thermodynamic Stable Serine Protease from Aspergillus fumigatus. Process Biochemistry, 46, 2001-2006.

https://doi.org/10.1016/j.procbio.2011.07.013

[42] Corrêa, A.P.F., Daroit, D.J. and Brandelli, A. (2010) Characterization of a Keratinase Produced by Bacillus sp. P7 Isolated from an Amazonian Environment. International Biodeterioration \& Biodegradation, 64, 1-6. https://doi.org/10.1016/j.ibiod.2009.06.015

[43] Bhunia, B., Basak, B., Mandal, T., Bhattacharya, P. and Dey, A. (2013) Effect of pH and Temperature on Stability and Kinetics of Novel Extracellular Serine Alkaline Protease (70 $\mathrm{kDa}$ ). International Journal of Biological Macromolecules, 54, 1-8. https://doi.org/10.1016/j.ijbiomac.2012.11.024

[44] Anitha, T.S. and Palanivelu, P. (2013) Purification and Characterization of an Extracellular Keratinolytic Protease from a New Isolate of Aspergillus parasiticus. Protein Expression and Purification, 88, 214-220. https://doi.org/10.1016/j.pep.2013.01.007

[45] Sankeerthana, C., Pinjar, S. and Jambagi, R. (2013) Production and Partial Characterization of Protease from Aspergillus flavus Using Rice Mill Waste as a Substrate and Its Comparison with Aspergillus niger. International Journal of Current Engineering and Technology, 
143-147.

[46] Kim, J. (2004) Purification and Characterization of an Extracellular Alkaline Protease from Aspergillus niger C-15. Mycobiology, 32, 74-78.

https://doi.org/10.4489/MYCO.2004.32.2.074

[47] Li, C., Xu, D., Zhao, M., Sun, L. and Wang, Y. (2014) Production Optimization, Purification, and Characterization of a Novel Acid Protease from a Fusant by Aspergillus oryzae and Aspergillus niger. European Food Research and Technology, 238, 905-917. https://doi.org/10.1007/s00217-014-2172-5

[48] Ire, F., Okolo, B. and Moneke, A. (2011) Purification and Characterization of an Acid Protease from Aspergillus carbonarius. African Journal of Food Science, 5, 695-709.

\section{Submit or recommend next manuscript to SCIRP and we will provide best service} for you:

Accepting pre-submission inquiries through Email, Facebook, LinkedIn, Twitter, etc. A wide selection of journals (inclusive of 9 subjects, more than 200 journals)

Providing 24-hour high-quality service

User-friendly online submission system

Fair and swift peer-review system

Efficient typesetting and proofreading procedure

Display of the result of downloads and visits, as well as the number of cited articles

Maximum dissemination of your research work

Submit your manuscript at: http://papersubmission.scirp.org/

Or contact aer@scirp.org 